\title{
FUNGSI RUANG TERBUKA DI SEKITAR KAWASAN RUMAH SUSUN: STUDI KASUS PADA RUMAH SUSUN BENDUNGAN HILIR 1
}

\author{
Yosica Mariana \\ Jurusan Arsitektur, Fakultas Sains dan Teknologi, Binus University \\ Jl. KH. Syahdan No. 9, Palmerah, Jakarta Barat 11480. \\ mariana_yosica@binus.ac.id
}

\begin{abstract}
The presence of a building, whether large or small, brings impacts on the environment. Residential houses, commercial buildings, office buildings or flats have both positive and negative impacts. This research aims to determine the changing function and utilization patterns of open green spaces in the some areas around a flat into built spaces. Rumah susun Bendungan Hilir 1 is purposively selected as the study site. The research method uses a descriptive survey is to make direct field observations. Based on the results it is showed that there is a land use change, especially in some areas directly adjacent to the flats, and a deviation on Spatial Plan as well as on the open space.
\end{abstract}

Keywords: flat, land use change, open green space.

\begin{abstract}
ABSTRAK
Kehadiran sebuah bangunan, kecil ataupun besar, tentu memiliki dampak terhadap lingkungan. Rumah tinggal, bangunan komersial, bangunan perkantoran ataupun rumah susun memiliki dampak positif ataupun negatif. Penelitian ini bertujuan untuk mengetahui proses alih fungsi dan pola pemanfaatan ruang terbuka hijau di kawasan sekitar rumah susun yang menjadi ruang terbangun. Rumah susun Bendungan Hilir 1 dipilih secara purposive sebagai lokasi penelitian. Metode penelitian menggunakan survey deskriptif yaitu dengan melakukan pengamatan langsung di lapangan (field observation). Berdasarkan hasil penelitian menunjukkan bahwa terjadi perubahan fungsi lahan (land use) terutama pada daerah yang berbatasan langsung dengan rumah susun tersebut dan penyimpangan pada Rencana Tata Ruang serta pada ruang terbuka.
\end{abstract}

Kata kunci : rumah susun, perubahan fungsi lahan, ruang terbuka hijau 


\section{PENDAHULUAN}

Suatu proses pembangunan akan membawa konsekwensi baik positif ataupun negatif, termasuk dalam pembangunan rumah susun. Ketika sebuah pembangunan dimulai pada suatu lahan, dimulai jugalah "tekanan” terhadap lingkungan sekitarnya. Diawali dengan kehadiran para pekerja proyek selama proses pembangunan, kemudian disertai dengan kemunculan sektor informal seperti warung-warung makan dan pedagang kaki lima. Seringkali kehadiran sektor informal ini bersifat "kagetan/dadakan", yang pada akhirnya menimbulkan ketidakteraturan dan berkesan kumuh pada lingkungannya. Bahkan terkadang, keadaan ini dijumpai ketika rumah susun tersebut sudah beroperasi. Tekanan pada lingkungan semakin bertambah, dengan kesibukan lalu lintas, volume limbah padat dan cair meningkat, hilangnya daerah resapan air hujan, pergeseran fungsi ruang terbuka dan tekanan-tekanan lainnya. Tekanan-tekanan ini merupakan permasalahan yang harus dipecahkan, terutama bagi rumah susun warga kota, yang justru diharapkan dapat memberikan nilai positif secara timbal balik terhadap lingkungan. Tekanan yang ditimbulkan oleh suatu bangunan terhadap lingkungan sekitarnya bermacam-macam, mulai dari tekanan terhadap utilitas kota, lalu lintas, ekonomi dan sosial masyarakat, ruang terbuka, tata guna lahan, dan lain sebagainya.

Penataan ruang di wilayah perkotaan perlu meperhatikan pengaturan antara ruang terbangun dan ruang tidak terbangun (ruang terbuka). Ketersediaan ruang terbuka kota sangat penting dalam perencanaan sebuah kota. Tetapi seiring dengan peningkatan jumlah penduduk kota, ketersediaan lahan untuk pemukiman masyarakat semakin sempit, sehingga penyediaan ruang terbuka dalam suatu lingkungan terkadang diabaikan.

Lokasi penelitian berada di Rumah Susun Bendungan Hilir 1 di Jl. Administrasi, Bendungan Hilir, Pejompongan, Jakarta Pusat. Dibangun pada tahun 1985 oleh Dinas Perumahan DKI Jakarta, rumah susun ini ditujukan untuk golongan masyarakat berpenghasilan rendah.

\section{Landasan Teori}

Budihardjo (2009) mengatakan bahwa penataan ruang dan pengelolaan wilayah di Indonesia masih relatif baru. Oleh karena itu masih banyak ditemui ketimpangan-ketimpangan dari rencana yang sudah ditetapkan. Secara umum, ada beberapa isu pokok dalam kaitannya dengan tata ruang dan pengelolaan wilayah di Indonesia yaitu keterpaduan perencanaan, orientasi dan motivasi perencanaan, kemitraan pemerintah dan swasta, partisipasi masyarakat, keterkaitan transportasi dan infrastruktur dan pertarungan perolehan lahan.

Berdasarkan Undang-undang No. 24 tahun 1992, tata ruang diartikan sebagai wujud struktural pemanfaatan ruang dan pola pemanfaatannya, baik yang direncanakan maupun tidak, yang menunjukkan adanya hirarki dan keterlibatan ruang. Ada tiga unsur utama di dalam penataan ruang yaitu: (1) perencanaan tata ruang yang dibedakan atas rencana tata ruang wilayah (RTRW) propinsi, kabupaten dan kota, serta rencana-rencana yang bersifat lebih rinci; (2) pemanfaatan ruang yang merupakan wujud operasionalisasi rencana tata ruang atau pelaksanaan pembangunan; (3) pengendalian pemanfaatan ruang, yang terdiri dari mekanisme perijinan dan penertiban terhadap pelaksanaan pembangunan agar tetap sesuai dengan rencana tata ruangnya.

Penataan ruang dalam wilayah perkotaan bertujuan agar pembangunan di kota tidak berkembang begitu saja tanpa arah dan mengabaikan lingkungan. Hal ini dapat membuat suatu kota menjadi tidak terarah, kacau dan tidak berkelanjutan. Supriyadi (2009) menjelaskan bahwa pembangunan kota yang tidak mengacu pada tata ruang akan menimbulkan berbagai konflik yang terkadang sulit untuk diuraikan dan dipecahkan. Konflik ini terjadi karena tingginya tingkat urbanisasi, yang mengakibatkan jumlah penduduk bertambah, kegiatan atau aktivitas meningkat sedangkan daya 
dukung lingkungan terbatas. Jakarta, Surabaya, Semarang, Bandung merupakan contoh dari kota yang proses pembangunannya tidak terkendali, dengan kesemrawutan dan kekumuhan akibat tumbuhnya perkampungan, pedagang kaki lima berjualan di badan jalan, pasar kaget di ruang terbuka (taman kota), pemukiman liar di sepanjang rel dan bantaran sungai dan lain sebagainya. Supriyatno (2009) mengatakan bahwa ruang terbuka ditinjau dari beberapa aspek memiliki banyak manfaat. Secara ekologis, ruang terbuka yang hijau dapat menurunkan temperatur kota, mengurangi polusi udara, mencegah banjir dan meningkatkan kualitas air tanah. Secara sosial budaya, keberadaan ruang terbuka dapat memberikan fungsi sebagai ruang berinteraksi, sarana rekreasi dan sebagai 'tanda' kota berbudaya. Wujudnya seperti taman kota, lapangan olah raga atau makam. Secara arsitektur, ruang terbuka dapat meningkatkan keindahan dan kenyamanan kota melalui keberadaan taman-taman kota, jalur-jalur hijau dan jalan-jalan kota. Sementara ditinjau dari sisi ekonomi, jika ruang terbuka hijau ini dikelola dengan baik dan menarik maka akan mengundang penghuni kota hadir berekreasi dan membangkitkan sektor ekonomi di sekitarnya seperti jasa parkir, warung, tempat makan dan sebagainya.

Pada seminar Nasional Arsitektur Peran Ruang Publik dalam Pengembangan Sektor Properti dan Kota, Menteri PU menyatakan "Ruang Publik dapat dirancang dengan baik sesuai dengan tata ruang kotanya, diharapkan dapat memenuhi kebutuhan masyarakat akan ruang terbuka, meningkatkan kualitas kehidupan, membentuk identitas komunitas, melindungi kualitas lingkungan dan meningkatkan nilai ekonomi bangunan atau properti pada lokasi yang berdekatan dengan ruang publik tersebut. Disamping itu, ruang publik juga berfungsi memberikan nilai tambah bagi lingkungan dari segi estetika kota, pengendalian pencemaran udara, pengendalian iklim mikro serta memberikan citra sebuah kota. Dalam konteks itulah, saya senantiasa mendorong berlakunya pendekatan penataan ruang digunakan sebagai landasan pelaksanaan pembangunan. Keberadaan penataan ruang dirasakan semakin penting dewasa ini, sejalan dengan kebutuhan kita bersama untuk mengupayakan penyelenggaraan pembangunan yang terpadu lintas sektor, lintas wilayah dan diantara pemerintah, swasta dan masyarakat menuju pemanfaatan ruang yang nyaman, produktif dan berkelanjutan.”

\section{METODE}

Penelitian ini menggunakan metode observasi deskriptif yang bertujuan untuk mengetahui, membandingkan dan menganalisis hubungan antara fungsi lahan yang ada dan ruang terbuka terhadap Rencana Tata Ruang pada area sekitar rumah susun yang dijadikan obyek pengamatan. Lokasi penelitian dilakukan pada rumah susun Bendungan Hilir 1 yang berada di daerah perkotaan dan cukup lama dihuni, sehingga dampaknya terhadap lingkungan sekitarnya sudah terlihat secara permanen. Pengumpulan data dilakukan dengan cara melakukan survei dan pengamatan pada lokasi penelitian. Metode pengamatan dilakukan untuk mendapatkan gambaran dan data mengenai pemanfaatan lahan di sekitar lokasi. Metode ini dilakukan melalui interprestasi dan penginderaan jauh. Pelaksanaan ini dilakukan dalam tiga tahapan yaitu: (1) persiapan (studi pustaka dan pengumpulan data dengan penginderaan jauh); (2) pengamatan langsung (survei) di lapangan dan (3) penyajian hasil. Metode survei dilakukan untuk mendapatkan data secara langsung mengenai penggunaan lahan yang ada dan keberadaan ruang terbuka di sekitar lokasi penelitian tersebut.

\section{HASIL DAN PEMBAHASAN}

Rumah Susun Bendungan Hilir 1 (Gambar 1) ini memiliki luas area \pm 0,7 ha dan dibatasi oleh (Gambar 5):

Utara: Rel Kereta Api dan Perumahan; Selatan SPBU, Jalan dan Perumahan; Barat: Perumahan; Timur: Jalan dan Perkantoran. 


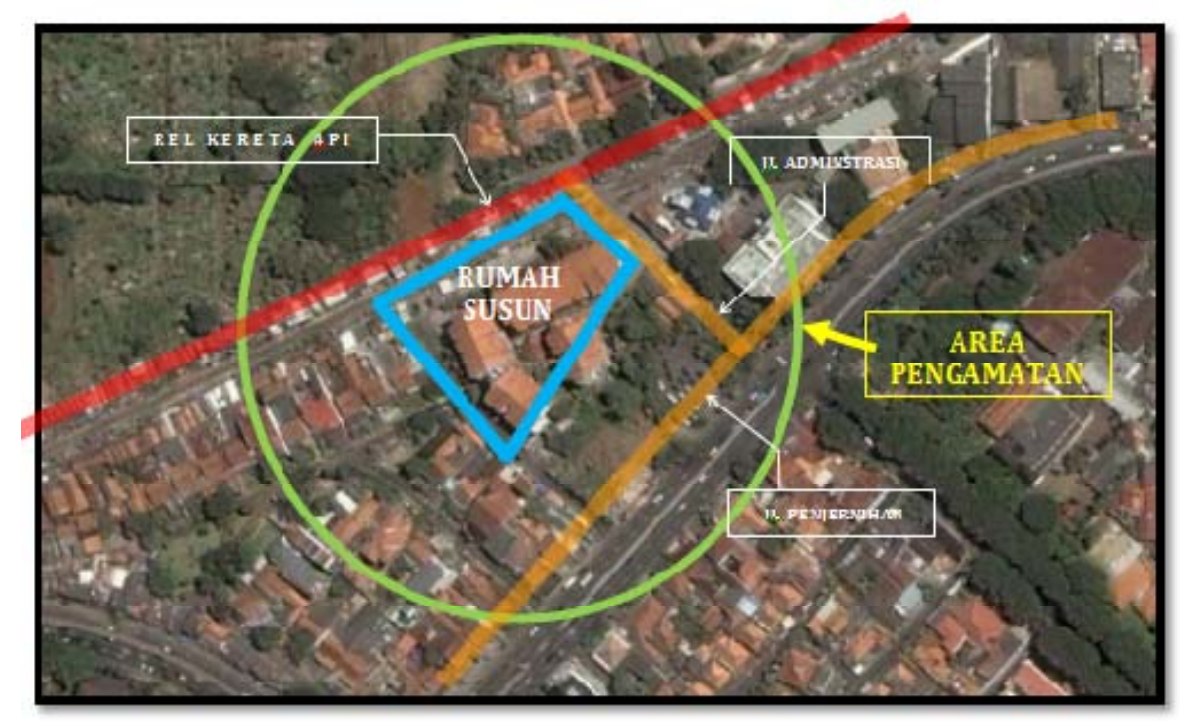

Gambar 5. Lokasi rumah susun Bendungan Hilir 1. Sumber: Google Maps, 2011

\section{Rencana Tata Ruang}

Dinas Tata Kota DKI Jakarta mengeiuarkan peta perencanaan untuk kawasan Rumah Susun Bendungan Hilir 1 dan sekitarnya yang didominasi untuk hunian dan perkantoran. Di sisi Barat, Selatan dan Utara, peruntukannya didominasi oleh hunian deirgan kode Wsd (wisma sedang) dan Wkc (wisma kecil). Pada sisi Timur, peruntukan diarahkan sebagai area hunian dengan kode Wkc (wisma kecil) dan Wsn (wisma susun). Agak menjorok ke arah Utara, terdapat ruang terbuka dengan kode Phm (penyempurna hijau makam), yang sekarang berfungsi sebagai tempat pemakaman petamburan dengan area yang cukup luas. Peruntukan untuk rencana perkantoran dan perdagangan berada di sepanjang Jl. Penjernihan dengan kode perencanaan Kkt (kantor jasa) dan Kpd (kantor perdagangan). Pada daerah Utara dari lokasi juga merupakan kantor pemerintahan dengan kode Kpm.

\section{Penggunaan Lahan}

Lokasi penelitian ini hampir dikelilingi oleh kawasan perumahan antara lain kompleks PAM dan kompleks Keuangan. Kawasan ini juga dilalui oleh jalan Penjernihan yang cukup strategis, dimana menghubungkan 2 daerah yaitu Jakarta Pusat dan Jakarta Selatan. Sepanjang jalan ini, banyak terdapat bangunan perkantoran dan bangunan perdagangan (toko). Penggunaan fungsi lahan yang paling menonjol adalah adanya SPBU Pertamina yang terletak di sebelah Tenggara rumah susun.

Posisi rumah susun ini agak masuk sekitar $100 \mathrm{~m}$ ke arah dalam dari Jl. Penjernihan. Letaknya hanya $\pm 1,5 \mathrm{~km}$ dari persimpangan flyover Jalan Gatot Subroto dengan Jalan Pejompongan serta \pm 3 km dari jembatan Semanggi, sehingga memiliki aksesibilitas yang cukup baik ke/dari rumah susun. Terutama karena Jalan Penjernihan selalu dilewati kendaraan umum selama 24 jam.

Area kawasan rumah susun umumnya memiliki pola ruang yang teratur karena terbentuk dari akses jalan yang ada. Rumah susun Bendungan Hilir 1 juga dikelilingi jalan pada beberapa sisinya. Di sisi Timur terdapat Jl. Administrasi 2, (lebar jalan sekitar $\pm 6 \mathrm{~m}$, dimana kondisi lalu lintasnya relatif sepi, walaupun merupakan akses utama menuju ke kawasan rumah susun). Jalan ini merupakan jalan lingkungan yang menghubungkan antara kawasan perumahan dengan jalan utama yaitu Jl. Penjernihan 
(jalan ini berada pada sisi Tenggara, memiliki lebar jalan sekitar $\pm 24 \mathrm{~m}$, terdiri dari 6 jalur berlawanan dengan kondisi lalu lintas padat terutama pada pagi dan sore hari). Pada sisi Utara, terdapat jalur kereta api Jabodetabek yang merupakan lintasan kereta api jurusan Tangerang/Serpong-Jakarta. Koridor ini relatif cukup sibuk mulai dari dini hingga malam hari dan seperti koridor kereta api lainnya di kota besar di Indonesia, koridor inipun dipenuhi oleh perumahan liar tidak permanen pada sisi utara berseberangan dengan rumah susun dan dipisahkan dengan tembok setinggi 2 meter (Gambar 6).

Kondisi lingkungan di sekitar rumah susun ini cenderung lebih teratur karena berada pada kawasan perumahan yang sudah tertata dengan baik dan umumnya dihuni oleh masyarakat menengah ke atas. Sementara, kondisi bangunan rumah susun Bendungan Hilir 1 kurang perawatan karena umumnya yang tinggal di sana merupakan orang yang menyewa/mengontrak, sehingga mereka kurang memperhatikan kondisi bangunan tersebut (Gambar 5 dan 6).

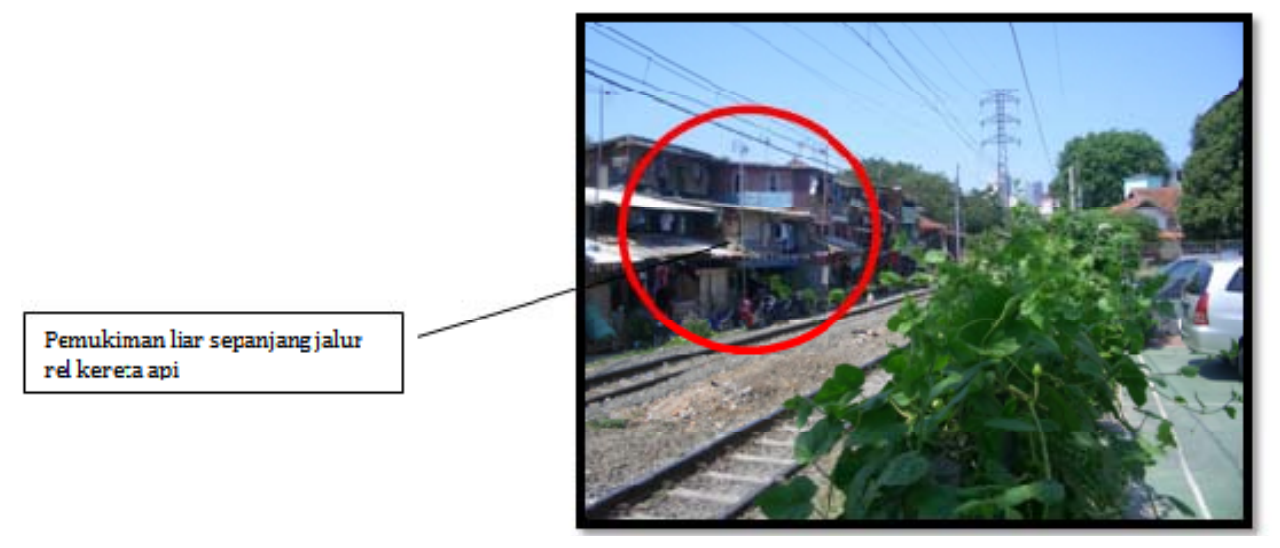

Gambar 4. Pemukiman liar di sepanjang rel kereta api. Sumber : Dokumentasi Penelitian Arsitektur Binus

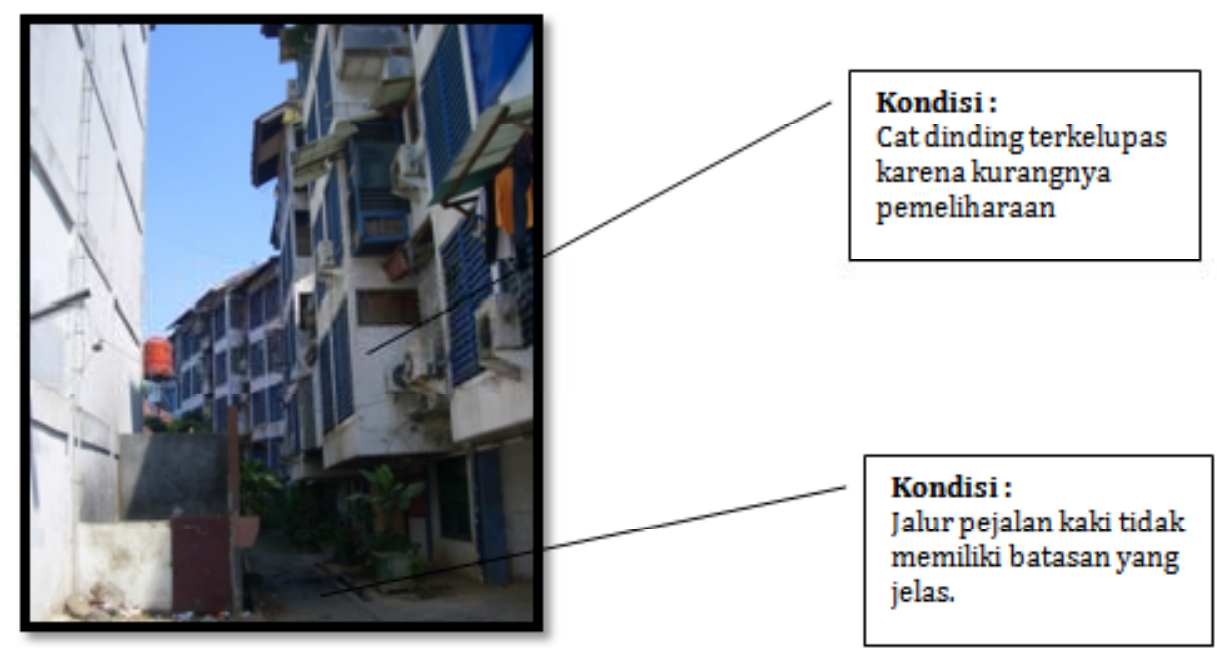

Gambar 5. Kondisi bangunan rusun.

Sumber : Dokumentasi Penelitian Arsitektur Binus 


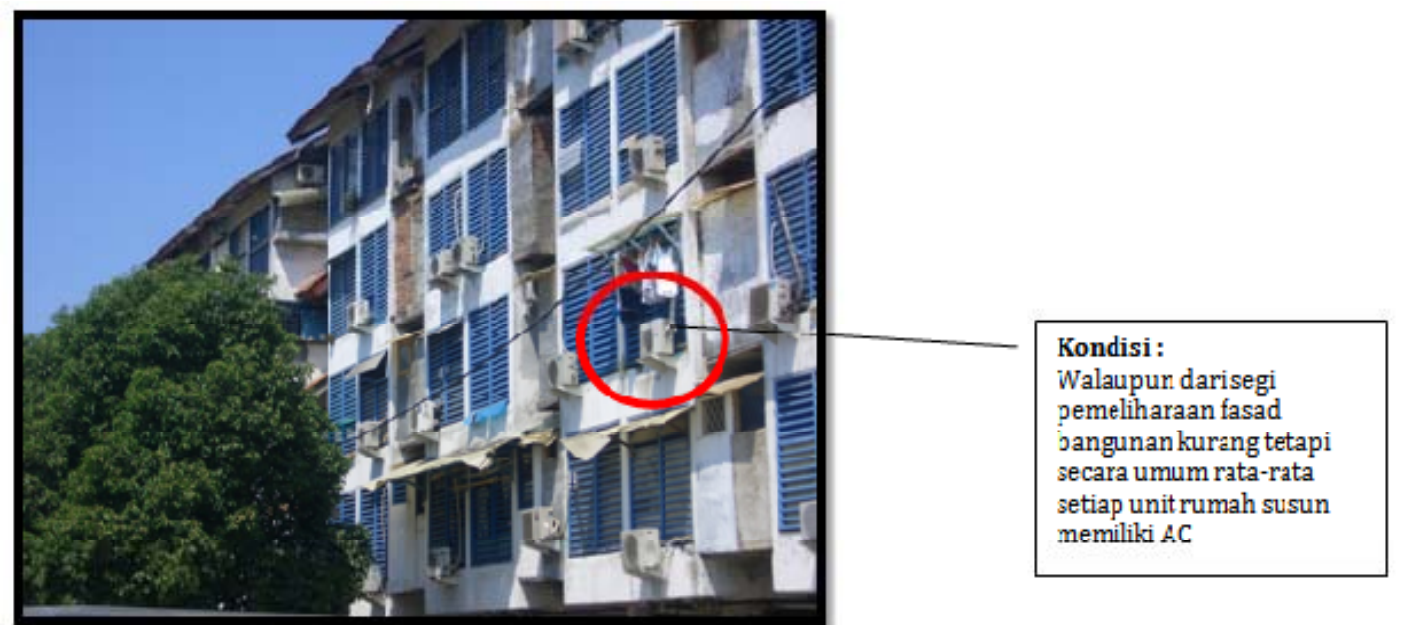

Gambar 6. Fasad bangunan Rusun yang kurang terpelihara Sumber : Dokumentasi Penelitian Arsitektur Binus

\section{Perbandingan Rencana Tata Ruang dengan Penggunaan Lahan}

Berdasarkan hasil pengamatan, tidak terdapat penyimpangan penggunaan lahan yang signifikan dari rencana tata ruang (Gambar 9) pada kondisi penggunaan lahan di lapangan (Gambar 10). Hanya ada beberapa penyimpangan yang umum terjadi. Pertama, perubahan fungsi di Jl. Administrasi 2, dari peruntukan untuk hunian (Wsn) dan perkantoran (Kkt dan Kpm) menjadi pertokoan (area perkantoran). Hal ini terjadi disebabkan oleh keberadaan rumah susun Bendungan Hilir 1. Dan kedua, terdapat pemukiman liar di sepanjang jalur lintasan kereta api. Walaupun posisinya terletak di seberang dari lahan rumah susun tersebut.

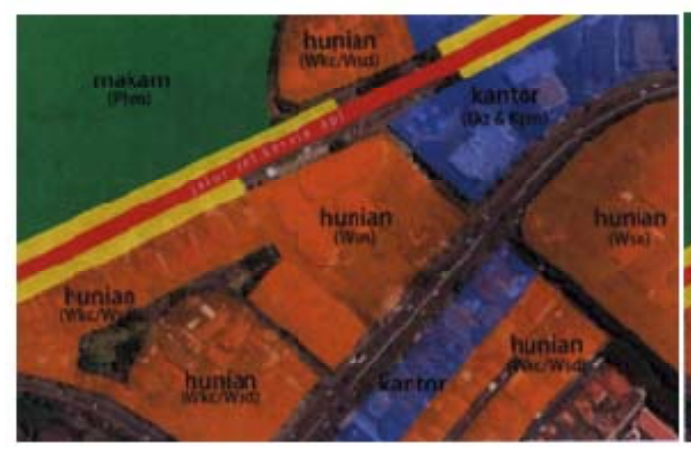

Gambar 9. Rencana Tata Ruang.

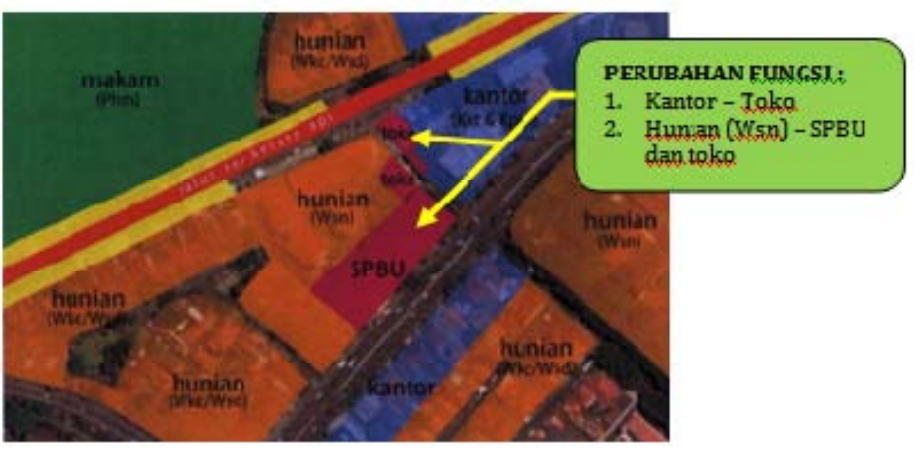

Gambar 10. Penggunaan lahan.

\section{Ruang Terbuka}

Pada kawasan sekitar Rumah Susun Bendungan Hilir 1, masih terdapat banyak ruang terbuka hijau. Yang paling menonjol adalah keberadaan Pemakaman Petamburan yang cukup luas di sebelah Utara yang terlihat ekstrim dibandingkan perumahan padat disekelilingnya, yaitu berupa ruang terbuka hijau dengan luas berkisar 8 ha yang cukup luas untuk ukuran kota Jakarta. Ruang terbuka lainnya memang lebih kecil, antara lain ruang terbuka hijau yang ada di komplek Keuangan sebelah Barat Daya Rumah susun yang berada ditengah-tengah area perumahan. Selanjutnya ruang-ruang terbuka hijau milik perorangan yang terdapat di halaman-halaman kantor terutama komplek perkantoran yang ada di sisi Utara. Ruang terbuka tersebut menjadi halaman samping dan tengah dari masing-masing 
komplek perkantoran dengan luasnya cukup besar dibandingkan dengan lahannya. Kualitas tamantaman tersebut juga cukup baik diisi oleh beragam tanaman yang rimbun. Ruang terbuka hijau juga terdapat di halaman belakang rumah susun Bendungan Hilir I, terdapat tanaman besar yang cukup rimbun. Selanjutnya adalah ruang-ruang terbuka yang berada di sisi timur dan selatan berupa tamantaman di halaman perkantoran dan perumahan. Ruang terbuka yang cukup menonjol di area ini adalah yang terdapat di komplek penjernihan PAM yang luasnya cukup besar. Dari sekian banyak ruang terbuka hijau yang ada disekitar rumah susun, sebagian besar memang milik perorangan, oleh karena itu keberadaannya tidak bisa diakses bebas oleh publik. Sebagaimana telah dijelaskan diatas, beberapa sisi dari lahan rumah susun Bendungan Hilir ini dikelilingi oleh jalan. Koridor jalan berfungsi juga sebagai ruang terbuka. Berbeda dengan ruang terbuka hijau yang sudah dijelaskan diatas, ruang terbuka koridor jalan dapat dimanfaatkan oleh semua orang (publik), oleh karena itu sesungguhnya lahan rumah susun ini dikelilingi pula oleh ruang terbuka. Pedestrian path, di sisi kanan dan kiri jalan sebagian dimanfaatkan oleh pedagang kaki lima untuk berdagang, sehingga pengguna jalan (pejalan kaki) terpaksa harus berjalan di jalan aspal (Gambar 7).

Di dalam kawasan rumah susun itu sendiri memiliki ruang terbuka yang cukup luas (Gambar 8). Saat ini, ruang terbuka tersebut hanya dimanfaatkan untuk parkir kendaraan (Gambar 9). Terkadang digunakan untuk pemanfaatan lain yang bersifat temporal seperti kegiatan tahunan (pemilu atau acara perayaan hari kemerdekaan RI warga sekitar rusun) (Gambar 10). Di tengah kawasan rusun, terdapat ruang terbuka yang digunakan sebagai taman, dimana pada sebagian dari taman tersebut dibangun mesjid beserta teras dan ruang wudhunya. Kondisi taman tersebut terbengkalai dan kurang terawat sehingga penuh sampah dedaunan dan kotor.

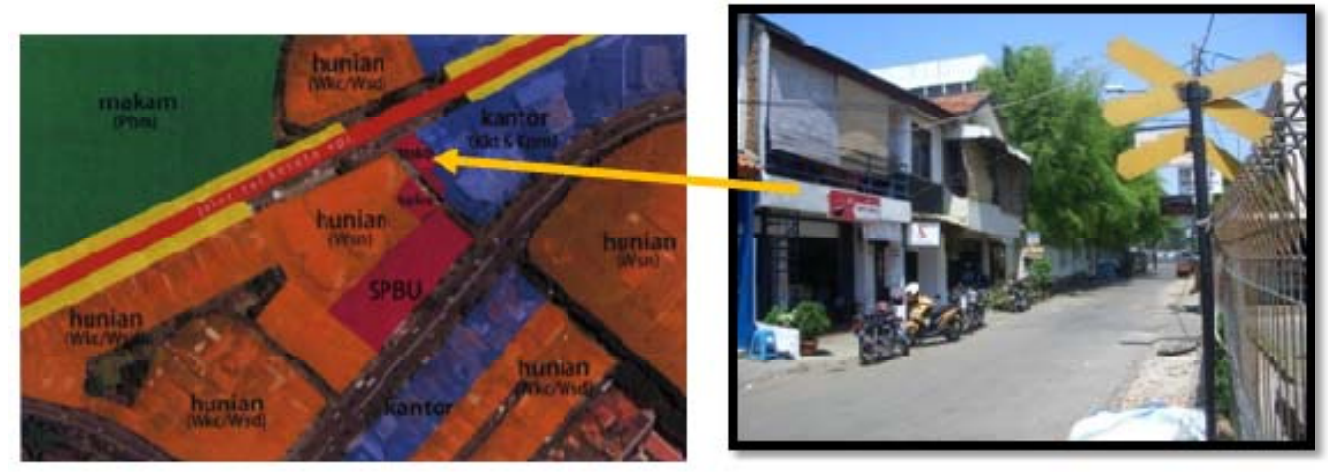

Gambar 7. Suasana di Jl. Administrasi 2, dimana jalur pejalan kaki berubah menjadi warung dan toko Sumber : Dokumentasi Penelitian Arsitektur Binus

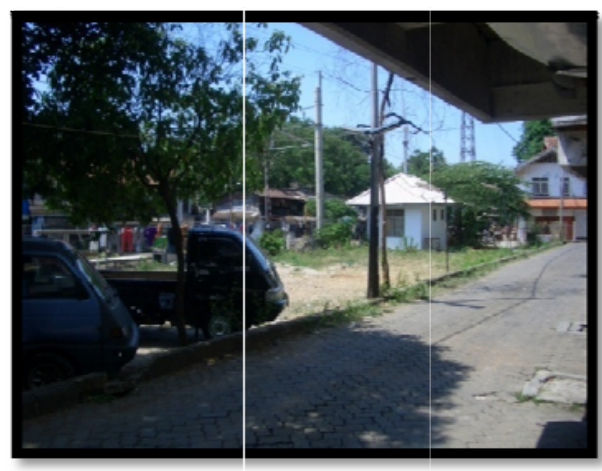

Gambar 8. Kondisi ruang terbuka di dalam kawasan Sumber : Dokumentasi Penelitian Arsitektur Binus

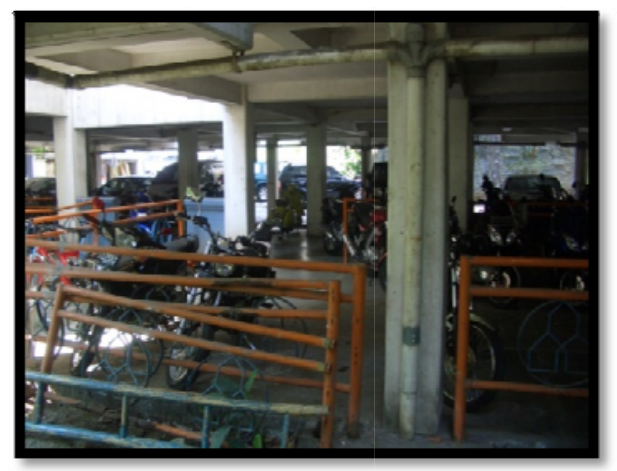

Gambar 9. Kondisi ruang terbuka berupa parkir motor Sumber : Dokumentasi Penelitian Arsitektur Binus 


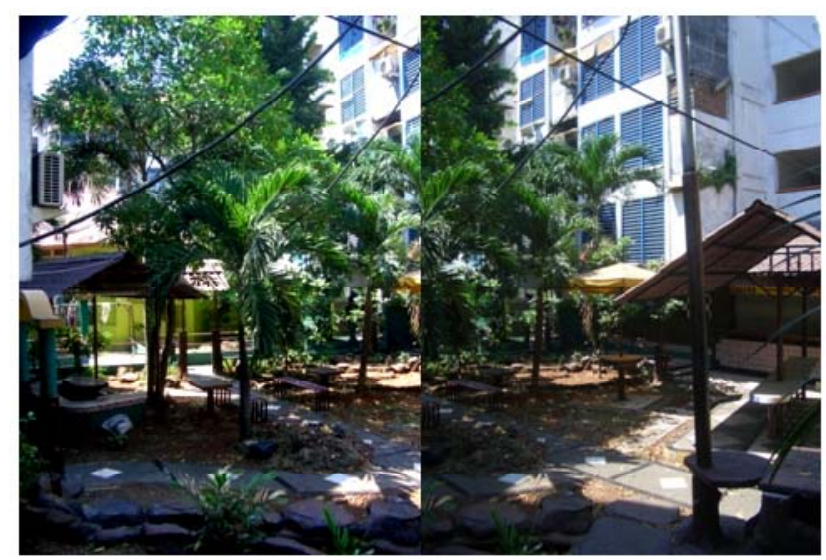

Gambar 10. Kondisi ruang terbuka hijau di dalam kawasan, berfungsi sebagai ruang komunal bagi warga rusun Sumber : Dokumentasi Penelitian Arsitektur Binus

\section{PENUTUP}

Kehadiran rumah susun sederhana secara umum memberikan dampak terhadap aspek tata ruang. Dampak yang signifikan terjadi adalah perubahan fungsi lahan (land use) terutama pada daerah yang berbatasan langsung dengan rumah susun tersebut. Biasanya perubahan fungsi itu dari bentuk hunian menjadi bentuk perdagangan (pertokoan). Skala besar atau kecilnya rumah susun mempengaruhi ketidaksesuaian tata ruang. Rencana Tata Ruang sebenarnya bertujuan untuk mengatur peruntukan lahan agar tidak bisa berubah semaunya, tetapi terkadang sering tidak digubris oleh pihak yang berwenang. Potensi kehadiran penghuni rumah susun, sering dianggap sebagai pangsa pasar bagi masyarakat di sekitar rumah susun tersebut, sehingga merubah rumah tinggal milik mereka menjadi toko atau ruang dagang. Penyimpangan Tata Ruang juga terjadi pada ruang terbuka, seperti perubahan dalam pemanfaatan koridor jalan menjadi tempat parkir dan berjualan dan perubahan fungsi trotoar menjadi tempat pangkalan ojek atau warung. Dalam perencanaan rumah susun, harus disediakan ruang non hunian untuk berdagang baik bagi penghuni ataupun masyarakat sekitarnya, calon penghuni harus tepat sesuai dengan tipikal rumah susun sehingga tidak ada perubahan 'tekanan' yang berlebihan bagi terhadap tata ruang maupun ruang terbuka. Diharapkan adanya pengawasan yang lebih konsisten dan berkala dari pemerintah daerah agar penyimpangan-penyimpangan tersebut dapat dihindari.

\section{DAFTAR PUSTAKA}

Budihardjo, Eko. (2009). Penataan Ruang dan Pembangunan Kota. Bandung: Alumni.

Republik Indonesia. (1985). Undang-Undang Republik Indonesia Nomor 16 Tahun 1985 tentang Rumah Susun. Jakarta.

Supriyatno, Budi. (2009). Manajemen Tata ruang. Jakarta: Media Brilian. 